INTERNATIONAL HIGHER EDUCATION, Number 70 Winter, 2013

Pages 11-12

\title{
Is Postsecondary Education Affordable?
}

SANDY BAUM and SAUL SCHWARTZ

Sandy Baum is a senior fellow at the George Washington University Graduate School of Education and Human Development. E-mail: sbaum@gwu.edu. Saul Schwartz is a professor in the School of Public Policy and Administration at Carleton University, Ottawa, Ontario, Canada. E-mail: saul_schwartz@carleton.ca. See the related working paper, Baum and Schwartz, "Toward a Realistic Conception of Postsecondary Affordability" (http: / / gsehd.gwu.edu/documents / gsehd / research/Working\%20Paper\%20Ser ies/WPS2.2_Baum_web.pdf) and policy brief, http: / / www.ihep.org/ publications / publications-detail.cfm?id=156.

The evolution of higher education from a privilege for the elite to an economic and social necessity for broad segments of the population has created financing challenges, along with new opportunities, for students and their families. Governments that were able to provide free or low-priced access to universities for the select few have found it necessary to charge rising levels of tuition, even as less-affluent citizens aspire to enroll. In a number of countries-including Canada, Chile, and England-students have taken to the streets to protest tuition policies. Students are less militant in the United States; but there, as elsewhere, rising college prices and stagnating incomes have led to the widespread 
perception that postsecondary education is "unaffordable" for more and more people.

Yet, it is not obvious what "unaffordable" means. What price is relevantthe published price of postsecondary study, the price people actually pay, or the price people should be expected to pay? Efforts to increase educational opportunity can be hindered if policymakers do not have a clear idea of the meaning of an "affordable" or "unaffordable" education.

\section{The Subjectivity of What Students Can Pay}

Purchases are objectively unaffordable if people do not have access to the cash to pay the asked-for price. While this may be the case for some potential postsecondary students, the widespread availability of government-sponsored student loans and grants makes this absolute constraint relatively uncommon. Rather, postsecondary study is considered unaffordable because it is expensive, requires the sacrifice of other goods and services, or involves the accumulation of debt.

Thus, affordability is subjective. Some parents make great sacrifices, in order to pay for the education of their children. Others, with greater resources, are unwilling to sacrifice current consumption for the uncertain benefits of higher education. The difference between these parents relates not only to their incomes but also in their preferences and priorities.

In addition, the status quo is the reference point for judging affordability. Québec students, with the lowest tuition in North America, took to the streets this past spring, when higher tuition rates were proposed-despite the relatively 
low charges there. German states introduced tuition fees in 2006, but protests by German students have contributed to a return to zero tuition in some cases.

\section{Net Price}

Perceptions of the price of postsecondary tuition are distorted by the visibility of published or "sticker" prices and the reality that many students pay significantly lower prices. Government-funded grant aid, institutional scholarships, tax credits, deferred payment through subsidized loans, and subsidies from other sources create a complex system that clearly lowers the price of education for some students but also makes predicting and understanding the price very difficult.

The gap between net price and actual price can be large. In 2007/08, the latest year for which data are available, low-income American students received enough grant aid, on average, to cover all tuition and fees at public two-year and four-year colleges. Nonetheless, that fact had little impact on the perception that rising prices put college out of reach for all but the most affluent students. In addition, to a lack of understanding of net prices, there is substantial evidence that most people overestimate the published prices. Policymakers must give careful consideration to policies that ensure both that postsecondary education is actually affordable and that it is perceived as affordable.

\section{POSTSECONDARY EDUCATION AS AN INVESTMENT}

One reason to care about affordability is that postsecondary education can provide low-income students with the opportunity to obtain better jobs and, as a result, to earn higher incomes over the long-term. Implicit in that concern is that 
postsecondary education is an investment that pays off over the life of the student. In the countries with high tuition, conversations about whether or not college is affordable would be strengthened by a focus on how much debt students can afford to repay-rather than how much of their current incomes parents can afford to devote to a year of college for their children.

Many students borrow to pay postsecondary costs. On average, these students can expect to repay their loans out of the earnings premium that results from their education. However, despite the high-average return to postsecondary education, the earnings of individuals vary at each level of educational attainment; college does not pay off well for everyone. Even if the expected return is high enough to make going to college a good economic choice, the risk of ending up with low earnings and an unmanageable debt burden may make the investment unappealing to some potential borrowers. The riskiness of the investment affects perceived affordability.

While the investment perspective implies that family income is not relevant, as long as there is no constraint on how much students can borrow, the funds that well-off parents give to their children diminish their need to borrow. In a more equitable world, all students would receive the same total subsidy, either from parents or from other sources. Government and institutions would fill the gap for students whose parents are in no position to pay.

\section{CONCLUSION}

As policymakers attempt to address the problem of funding postsecondary education in an environment of rising prices, strained government budgets, and 
limited household resources, it is useful to think about what it really means for postsecondary education to be affordable.

Affordability is subjective. It depends on preferences as well as available resources and prices. Moreover, judgments about whether or not prices are too high depend on familial expectations and on views about how the cost of education should be shared between students and society. Those judgments are also affected by the status quo; when low tuition is increased, concerns about affordability also increase-even if the new level of tuition remains low compared to higher tuition systems.

While many students and families confront real difficulties paying for study, the perception of affordability is sometimes worse than the realitybecause both people believe published prices are higher than they actually are and also many students and families are unaware of the magnitude of the financial aid available to them.

Postsecondary education is an investment with a high-average rate of return, but it is an uncertain investment that does not always pay off. A weak economy increases the uncertainty associated with the level and timing of the return to this investment. This uncertainty may make postsecondary study seem unaffordable.

The costs and risks associated with postsecondary education are most detrimental for students whose families are unable to provide significant financial assistance. Grant aid for low- and moderate-income students can substitute for parental support, reducing the extra risk that low-income students take on because of their greater need to borrow. 